\title{
Comparative Life Table Parameters of the Vine Mealybug, Planococcus ficus (Signoret) (Hemiptera: Pseudococcidae), Fed on Some Ornamental Plants. Ghada S. Mohamed Plant Protection Department, Faculty of Agriculture, South Valley University, Qena, Egypt
}

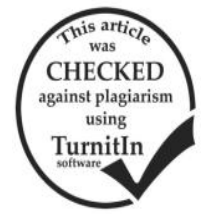

\section{ABSTRACT}

This study aimed to assessment survivorship and fecundity of the vine mealybug, Planococcus ficus (Signoret) reared on different hosts (Hedra helix L., Pittosporum tobira (Thunb.) and Nerium oleander L.). The experiment was carried under laboratory conditions, life table and population parameters were structure to assessment survivorship in all stages of the vine mealybug life cycle. Results displayed that the highest mortality existed in the immature stages (nymphal stages) for all hosts were $32.02,42.05$ and $56.63 \%$ and the total mortality were $35.89,48$ and $64.50 \%$ on H.helix, P. tobira and N. oleander on respectively. Fertility tables showed that the net reproductive rate $\left(\mathrm{R}_{0}\right)$ of population were $(105.08,58.90$ and 54.11$)$, mean generation time $(\mathrm{T})$ were $(27.42,40.33$ and 43.68$)$, innate capacity for increase $(\mathrm{r})$ were $(0.17,0.10$ and 0.09$)$, finite rate of increase $(\lambda)$ were $\left(1.85,1.11\right.$ and 1.09) and the population doubling time $\left(\mathrm{D}_{\mathrm{T}}\right)$ were within $(4.08,6.93$ and 7.70 day) for three hosts on respectively. According to the results, it could be concluded that the survivorship curve of Planococcus ficus (Signoret) approach to a diagonal model curve, which reflects a humble rate of mortality through life stages and piecemeal decreasing when oncoming adulthood with a significant effect of food preference for H.helix comparative with P. tobira and N. oleander.

Keywords: Vine mealybug, Planococcus ficus, life table, fecundity parameters and ornamental plants.

\section{INTRODUCTION}

The vine mealybug, Planococcus ficus (Signoret) considered as a local pest of the North Africa region and it converted to the main pest in the cultivation of grapes in many countries around the world such as USA, Turkey, Morocco, Italy, France, Spain and South America .The vine mealybug has been recorded on many different plant hosts such as mango, avocado, date palm, pomegranate, apple and ornamental plants in addition to grapes (Daane et al., 2012). The life cycle of the vine mealybug included three female nymphal phases and it has nearly 5 to 8 generations over the year, Influenced by many weather elements, the most important effect of it revealed to temperature and humidity. Planococcus ficus feeds on sucking plant sap from bark in all grapevine parts, creating in shriveling, deformed and pallid leaves, precocious leaf falling, and flagging development and sometimes kill infected plants or parts of them (Kosztarab and Kozar 1988). P. ficus cause many damages in host plants even if the numerical density of this pest is low, mainly because its transfer the grapevine leafroll-associated virus (GLRaV) (Cabaleiro and Segura 1997) and secretes large quantity of the of honeydew, which helps the black sooty mold fungus to grow on leaves and fruits plus reduces their marketing value (Sforza et al., 2005 and Daane et al., 2006).

Life tables are one of the most important methods which used in realization population dynamics and evaluation the growth parameters and reproduction potential of insect populations (Chi and $\mathrm{Su} 2006$ ). Life table studies are predominantly utilized by researchers as a technique of evaluating the growth of populations and predicting the dimension of a population. The life table providing a full description which involves the specifics of development times, the survival rates of each development stage, and the fecundity and life expectancy of a population (Carey 1993 and Yang et al. 2013).

Assessing the survivorship in a population and the fecundity of adults supply substantial birth to death acquaintance of individuals in the association (Carey 1993). fundamental parameters can be evaluated out of life table analysis, and they can be utilized to predict insect action and reconnoiter mortality and increasing types of a population appropriate host are one of the most substantial agents affecting the biology of insects (Price et al. 1980). By recognize the life table parameters of the vine mealybug on various host plants, its host plant appropriate can be specified on host plants. Therefore, information on the suitable use of these plants in parks and large squares can be provided. However, their importance of P. ficus as a pest, no comparison studies on the biology of $P$. ficus breed on several host plants have been executed.

The purpose of the current studies was to estimate some biological characteristic, such as number surviving individuals at beginning of each age (lx), gross reproductive rate $(\Sigma \mathrm{mx})$, net reproductive rate (Ro), mean length of a generation (T), innate capacity for increase (r), finite rate of increase/ day $(\lambda)$ and doubling time (DT), moreover the life table parameters of $P$. ficus when breed on three plants, H.helix, $P$. tobira and $N$. oleander provide a better understanding information about the appropriate phonological stage for growth and forecast of $P$. ficus distribution

\section{MATERIALS AND METHODS}

\section{Plants and the vine mealybug, Planococcus ficus cultures}

Host plants (Hedra helix L., Pittosporum tobira (Thunb.) and Nerium oleander L.) were obtained from The Agricultural Experimental Station of the Faculty of Agriculture, Assiut University where the growth of plants in natural light. The plants were preserved under the environmental chamber conditions. The ovisacs of the vine mealybug, $P$. ficus were obtained from H.helix plants were placed over pumpkin. The pumpkin was infested with mealybugs kept in the cylindrical plastic cage with $30 \mathrm{~cm}$ diameter in a climate chamber. The vine mealybug was reared for one generation on all kinds of ornamental plants which used in the experiment. After 30-40 days of colony formation on each plant, the 10- day old adult females was collected by a brush from the three ornamental plants for use in the experiment Construction of life table:

Newly emerged adults female were obtained from laboratory culture and transferred to three ornamental plant leaves in petri plates for oviposition. One day old eggs were gathered for the construction of life tables. To 
regulate the life tables were taking number of eggs laid by the females consisting of 560, 475 and 507 eggs on the leaves of $H$. helix, $P$. tobira and $N$. oleander respectively. The number of eggs, which taken are differed depending on the number of eggs, which female laid on each ornamental plants. For life table study $9 \mathrm{~cm}$ diameter plastic petri plates were utilized. About $0.5 \mathrm{~cm}$ diameter pit was made in the bottom of the petri plate utilizing a heated Iron nail for the stalk of each ornamental plants leaf and the cover of petri plate was cut off in the center in square form about $5 \mathrm{~cm}$ diameter to stick muslin cloth with glue to allow the air spread out inside the Petri plate. The three ornamental plants leaf with a 3-4 cm long stem was placed in each Petri plate with the stalk entered through the pit at the bottom of the Petri plate. All of Petri plate with ornamental plants leaf was put in a glass of water so that the stems to be submerged for preserve leaf vitality. Eggs were distributed on Petri plates and the petri plate was locked around by utilizing parafilm to avert the exit of mealybug nymphs. Survival and fecundity of each individual were recorded till the death of the last individual according to (Mastoi et al. 2014).

\section{Data analysis:}

Life and fecundity tables were constructed from a daily account of mortality and fecundity of three ornamental plant leaves cohorts subsequent accomplishment of Birch (1948) and South wood (1978). The parameters calculated were as follows: $\mathrm{x}$ : age class in units of time (days) / developmental stage lx:number surviving individuals at beginning of age $\operatorname{class}(\mathrm{x})$

$\mathrm{L}_{\mathrm{x}}$ : number of individuals alive between age and the age period that followed

$\mathrm{d}_{\mathrm{x}}$ :number dying during age interval $\mathrm{x}$

100qx : Percent apparent mortality, 100qx $=(\mathrm{dx} / \mathrm{lx}) 100$

$\mathrm{S}_{\mathrm{x}}$ : survival stage rate within stage

$\mathrm{T}_{\mathrm{x}}$ : total number of age $\mathrm{x}$ units beyond the age $\mathrm{x}$

$\mathrm{e}_{\mathrm{x}}$ : life expectancy for individuals of age $\mathrm{x}, \mathrm{e}_{\mathrm{x}}=\mathrm{T}_{\mathrm{x}} / \mathrm{l}_{\mathrm{x}}$
$X$ : Actual female age (time from eggs).

$\mathrm{mx}$ : age-specific fertility, the number of living females born per female in each age interval

Ro:net reproductive rate, multiplication rate per generation,

$\mathrm{Ro}=\Sigma 1 \mathrm{xmx}$

$\mathrm{T}$ : corrected generation time, $\mathrm{T}=\ln \mathrm{Ro} / \mathrm{r}$

$\mathrm{D}_{\mathrm{T}}$ :doubling time, the number of days required by a population to double, DT $=\ln 2 / \mathrm{r}$

$\mathrm{R}$ :innate capacity for increase, $\mathrm{r}=\ln$ Ro $/ \mathrm{T}$

$\lambda$ : finite rate of increase, $\lambda=\mathrm{e}^{\mathrm{r}}$

\section{RESULTS AND DISCUSSION}

Studying life tables are mostly utilized by researchers as a technique for estimating the development of populations and forecasting the volume of a population. The life table supplies a full description implicate the specifics of development times, the survival rates of each growth stage, and the fecundity and life anticipation of a population Yang et al. (2013). Host plant species are an essential agent in the outgrowth of Mealybugs; the development of the mealybugs was considered as a symbol of the goodness of that host plant to avail as a food exporter for its development. Most of our results are in assent with Patil et al. (2011) and Rashid et al. (2012).

1-Age-Specific Survival Life Table:

Data present in Tables (1, 2 and 3) indicated that the high mortalities were registered in nymphal stages particularly in early instar stage, then progressively reduce in later instars. The highest mortality was recorded in the first instar nymphs (18.16, 22.95 and 28.84) followed by second instar nymphs $(9.40,12.15$ and 19.95) and third instar nymphs (7.71, 9.57 and 15.63) on three ornamental plant leaves $H$. helix, $P$. tobira and $N$. oleander respectively.

Table 1. Life Table of Vine mealybug, P. ficus on $h$. helix

\begin{tabular}{lccccccc}
\hline $\mathbf{x}$ & $\mathbf{I}_{\mathbf{x}}$ & $\mathbf{L}_{\mathbf{x}}$ & $\mathbf{d}_{\mathbf{x}}$ & $\mathbf{1 0 0}_{\mathbf{q x}}$ & $\mathbf{s}_{\mathbf{x}}$ & $\mathbf{T}_{\mathbf{x}}$ & $\mathbf{e}_{\mathbf{x}}$ \\
\hline Eggs & 560 & 547 & 30 & 5.36 & 94.64 & 2069 & 3.69 \\
$1^{\text {st }}$ instar & 534 & 490.5 & 97 & 18.16 & 81.84 & 1522 & 2.85 \\
$2^{\text {nd }}$ instar & 447 & 431 & 42 & 9.4 & 90.6 & 1031.5 & 2.31 \\
$3^{\text {rdinstar }}$ & 415 & 404 & 32 & 7.71 & 92.29 & 600.5 & 1.45 \\
Adults & 393 & 196.5 & & & & & \\
\hline
\end{tabular}

Highest mortality in the first instar nymphs may be due to overcrowding along the basal part of the midrib of leaf and can be considered as the key element in organizing population volume. The high mortality in 1st instar nymphs was also reported in many insects especially in Lygus bug, plant hopper and citrus psyllid (Siswanto et al. 2008, Win et al. 2011 and Sule et al. 2012).

Table 2. Life Table of Vine mealybug, P. ficus on P. tobira

\begin{tabular}{lccccccc}
\hline $\mathbf{x}$ & $\mathbf{I}_{\mathbf{x}}$ & $\mathbf{L}_{\mathbf{x}}$ & $\mathbf{d}_{\mathbf{x}}$ & $\mathbf{1 0 0}_{\mathbf{q x}}$ & $\mathbf{S}_{\mathbf{x}}$ & $\mathbf{T}_{\mathbf{x}}$ & $\mathbf{e}_{\mathbf{x}}$ \\
\hline Eggs & 475 & 457.5 & 43 & 9.05 & 90.95 & 179.5 & 3.93 \\
$1^{\text {st }}$ instar & 440 & 417.5 & 101 & 22.95 & 77.05 & 1339 & 3.04 \\
$2^{\text {nd }}$ instar & 395 & 385.5 & 48 & 12.15 & 87.85 & 921.5 & 2.33 \\
$3^{\text {rd }}$ instar & 376 & 362 & 36 & 9.57 & 90.43 & 536 & 1.43 \\
Adults & 348 & 174 & & & & & \\
\hline
\end{tabular}

Overall, nymphal stage recorded the highest mortality rate in view of the length of the nymphal period compared to the remnant of other stages. The mortality percentage of the nymphal stage record 30.02 , 42.05 and $56.63 \%$ on H. helix L., P. tobira (Thunb.) and
$N$. oleander L. respectively. Generality of our results are consent with Tok et al. (2016) in Turkey, when they studied the life tables of the Madeira mealybug Phenacoccus madeirensis Green were reared in the laboratory under control conditions on for ornamental 
plant species. The mortality percentage of the nymphal stage record $1.0,6.9,10.8$ and $11.1 \%$ on Cestrum nocturnum, Pelargonium zonale, Hibiscus syriacus and Hibiscus rosa-sinensis respectively.

Table 3. Life table of Vine mealybug, P.ficus on $N$. oleander

\begin{tabular}{lccccccc}
\hline $\mathbf{x}$ & $\mathbf{l}_{\mathbf{x}}$ & $\mathbf{L}_{\mathbf{x}}$ & $\mathbf{d}_{\mathbf{x}}$ & $\mathbf{1 0 0}_{\mathbf{q x}}$ & $\mathbf{s}_{\mathbf{x}}$ & $\mathbf{T}_{\mathbf{x}}$ & $\mathbf{e}_{\mathbf{x}}$ \\
\hline Eggs & 507 & 491 & 58 & 11.44 & 88.56 & 1804.5 & 3.56 \\
$1^{\text {st }}$ instar & 475 & 430.5 & 137 & 28.84 & 71.16 & 1313.5 & 2.77 \\
$2^{\text {nd }}$ instar & 386 & 369 & 77 & 19.95 & 80.05 & 883 & 2.29 \\
$3^{\text {rd }}$ instar & 352 & 345 & 55 & 15.63 & 83.37 & 514 & 1.46 \\
Adults & 338 & 169 & & & & & \\
\hline
\end{tabular}

The percentage of mortality in egg stage registered 5.36, 9.05 and $11.44 \%$ on ornamental plant species, $H$. helix L., P. tobira (Thunb.) and N. oleander L., respectively, which represent the hatching percentage on leaves of the three ornamental plants, which due to the Physiological reasons for the infertility and other genetic factors. Consistent with our results Mastoi et al. (2011) reported that the percentage of mortality in egg stage recorded $5.66 \%$ when they studied the life table of Paracoccus marginatus Wlliams on Hibiscus sp.

In general, the tables (1,2 and 3) showed that the total percentage of the mortality of the vine mealybug, $P$. ficus was $35.89,48.00$ and $64.50 \%$ on the three ornamental plant species, H. helix L., P. tobira (Thunb.) and $N$. oleander L., respectively. The study goes in the same line of the findings of Mastoi et al. (2011) who found that the total percentage of the mortality of $P$. marginatus on Hibiscus sp. recorded $36.38 \%$. In line with the present findings, also Kumar et al. (2013) observed up to $59 \%$ total percentage of the mortality of Phenacoccus solenopsis Tinsley on different phonological phase of cotton growth.

Survivorship curves $\left(1_{\mathrm{x}}\right)$ of $P$. ficus studies on tree ornamental plant species in figure (1) showed that theses curves started with moderate mortality rates in the early stages of $P$. ficus life, followed by a gradual decrease when reaching adulthood for all three ornamental plant species. The results indicated that the survivorship curve of $P$. ficus identical to the diagonal model curve which distributing by Pearl (1928) and Schowalter (2011). Results also demonstrate that the humble rate of mortality through life stages and piecemeal decreasing when approximating adult stage with considerable influence of food priority for H.helix relative with $P$. tobira and $N$. oleander.

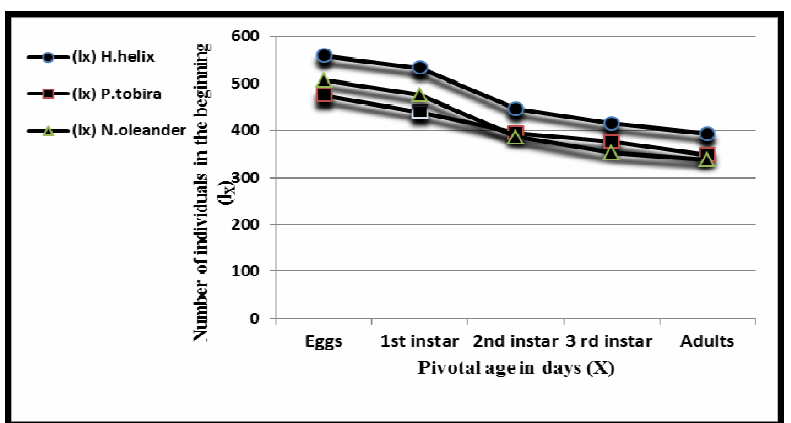

Fig. 1. The age-stage specific survival rates of $P$. ficus on three different host plants

Food effect, as shown clearly in the ability to survive (the number of individuals alive for different age) of the P. ficus on the H. helix L. leaves, which recorded the highest rates compared to leaves of $P$. tobira (Thunb.), followed by $N$. oleander L. This showed food preference for an insect on the leaves of $H$. helix.

In this field, there are diverse studies on the influence of host plants on the evolution and increase parameters of mealybug insect pests such as Phenacoccus solenopsis Tinsley (Hemiptera: Pseudococcidae) on four decorative plants Filiz et al. (2016), Pseudococcus comstocki (Kuwana) on Morus spp. Ataş and Kaydan(2014), Pseudococcus cryptus Hempel on Citrus spp. (Rutaceae) Holat et al. (2014), Planococcus citri Risso on citrus, grape and guava Ahmed and Abd-Rabou ( 2010) and Planococcus citri Risso on different decorative plants Polat et al. (2008).

From previous researches that reported, it was explained that the species of host plant affected in the Biological traits and life table parameters of the insects. The selection of phytophagous insects for host plants depends on the behavioral response of insects to the morphological and chemical properties of plants. Morphological characteristics of the host plant have an essential role in the acceptability of the host by the insect, either directly by visual cues or indirectly by affecting the strength of the insect to walk on or penetrating the plant tissue. Moreover, the differences in concentrations of nutrients in the host plant have a large impact in the selection of insect species. Chemical features found in certain parts of the plant are considered attractive for most types of phytophagous insects, and this will define the physical and chemical proportion to which the insect will react Bernays and Chapman (1994). Obviously, some scientists declare that several mealybug species show the different reaction to various plant species that have different morphological and chemical characteristic (Yang and Sadof 1995; Tobih et al 2002 and Hogendorp et al 2006). However, we did not concentrate on morphological and/or chemical properties of the experiment plants and their influence on the biological characters of the vine mealybug, $P$. ficus (Signoret) in this search.

Age-Specific fecundity table:

Age-specific survivorship $\left(\mathrm{l}_{\mathrm{x}}\right)$ and fecundity $\left(\mathrm{m}_{\mathrm{x}}\right)$ of the vine mealybug, $P$. ficus (Signoret) on three ornamental plant leaves are shown on a comprehensive data in Tables (4, 5 and 6) and figure (2). The first adult female appeared on day $(20,35$ and 38$)$ and the precocious egg laying was recorded just after (5, 3 and 3 ) days of female emergence and egg laying almost continued till the death. On the other hand the first adult female death was recorded in the 36, 46 and 49 day on three ornamental plant leaves $H$. helix L., $P$. tobira (Thunb.) and $N$. oleander L. respectively. 
Table 4. Age -specific life and fecundity table of $P$. ficus on H.helix

\begin{tabular}{lcccc}
\hline $\mathbf{X}$ & $\mathbf{L}_{\mathbf{x}}$ & $\mathbf{M}_{\mathbf{x}}$ & $\mathbf{L}_{\mathbf{x}} \mathbf{M}_{\mathbf{x}}$ & $\mathbf{X L}_{\mathbf{x}} \mathbf{M}_{\mathbf{x}}$ \\
\hline $0-20$ & immature stage & & & \\
24 & pre-oviposition & & & \\
25 & 0.55 & 58.33 & 32.08 & 802.00 \\
26 & 0.48 & 43.11 & 20.69 & 537.94 \\
27 & 0.41 & 37.17 & 15.24 & 411.48 \\
28 & 0.36 & 25.07 & 9.03 & 252.84 \\
29 & 0.33 & 20.58 & 6.79 & 196.91 \\
30 & 0.31 & 18.16 & 5.63 & 168.90 \\
31 & 0.29 & 16.02 & 4.65 & 144.15 \\
32 & 0.27 & 13.71 & 3.70 & 118.40 \\
33 & 0.24 & 11.06 & 2.65 & 87.45 \\
34 & 0.21 & 9.75 & 2.05 & 69.70 \\
35 & 0.18 & 7.37 & 1.33 & 46.55 \\
36 & 0.14 & 5.96 & 0.83 & 29.88 \\
37 & 0.11 & 2.18 & 0.24 & 8.88 \\
38 & 0.08 & 1.86 & 0.15 & 5.70 \\
39 & 0.05 & 0.35 & 0.02 & 0.78 \\
40 & 0.02 & 0.17 & 0.00 & 0.00 \\
41 & 0.01 & 0 & 0.00 & 0.00 \\
\hline Total & & 270.85 & 105.08 & 2881.56 \\
\hline
\end{tabular}

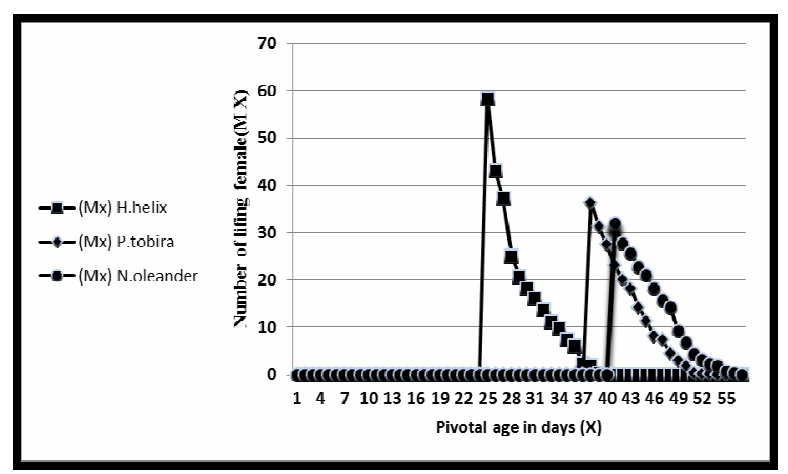

Fig. 2. The female fertility of on three different host plants

The last female died on day (41, 54 and 56). Results also showed the pre-oviposition took about several hours on leaves of $H$. helix $\mathrm{L}$. and one day on leaves of $P$. tobira (Thunb.) and $N$. oleander L. respectively. Tables generally showed that adult female laid the greatest number of eggs in precocious day oviposition whereas the minimum numbers of eggs were laid in later days of adult female life length.

Table 5. Age -specific life and fecundity table of $\boldsymbol{P}$. ficus on P.tobiro

\begin{tabular}{lcccc}
\hline $\mathbf{X}$ & $\mathbf{L}_{\mathbf{x}}$ & $\mathbf{M}_{\mathbf{x}}$ & $\mathbf{L}_{\mathbf{x}} \mathbf{M}_{\mathbf{x}}$ & $\mathbf{X L}_{\mathbf{x}} \mathbf{M}_{\mathbf{x}}$ \\
\hline $0-35$ & immature stage & & & \\
$36-37$ & pre-oviposition & & & \\
38 & 0.41 & 36.31 & 14.89 & 565.82 \\
39 & 0.38 & 31.25 & 11.88 & 463.32 \\
40 & 0.35 & 27.45 & 9.61 & 384.40 \\
41 & 0.31 & 23.14 & 7.17 & 293.97 \\
42 & 0.27 & 20.07 & 5.42 & 227.64 \\
43 & 0.22 & 18.11 & 3.98 & 171.14 \\
44 & 0.17 & 14.16 & 2.41 & 106.04 \\
45 & 0.14 & 11.37 & 1.59 & 71.55 \\
46 & 0.11 & 8.1 & 0.89 & 40.94 \\
47 & 0.08 & 7.35 & 0.59 & 27.73 \\
48 & 0.07 & 4.44 & 0.31 & 14.88 \\
49 & 0.04 & 3.03 & 0.12 & 5.88 \\
50 & 0.02 & 1.77 & 0.04 & 2.00 \\
51 & 0.02 & 0.22 & 0.00 & 0.00 \\
52 & 0.02 & 0.15 & 0.00 & 0.00 \\
53 & 0.01 & 0.1 & 0.00 & 0.00 \\
54 & 0.01 & 0 & 0.00 & 0.00 \\
\hline Total & & 207.02 & 58.90 & 2375.31 \\
\hline
\end{tabular}

Many researchers reported that the Fecundity, preoviposition, oviposition, postoviposition time and longevity of the mealybug insects were influenced by host plant kinds. Ahmed and Abd-Rabou (2010) mention that the host plant species impacted on pre-oviposition, oviposition, postoviposition periods of $P$. citri Risso, Arif et al. (2013) obtained the highest fecundity of phenacoccus solenopsis Tinsley on Hibiscus sp. among 25 various guest plants and Filiz et al. (2016) Proved that the longest oviposition span was noted when breeding mealybug on Hibiscus rosa, whereas the shortest one was recorded on Cestrum laevigatum.

Table 6. Age -specific life and fecundity table of $\boldsymbol{P}$. ficus on N.oleander

\begin{tabular}{lcccc}
\hline \multicolumn{5}{c}{ ficus on N.oleander } \\
$\mathbf{X}$ & $\mathbf{L}_{\mathbf{x}}$ & $\mathbf{M}_{\mathbf{x}}$ & $\mathbf{L}_{\mathbf{x}} \mathbf{M}_{\mathbf{x}}$ & $\mathbf{X L}_{\mathbf{x}} \mathbf{M}_{\mathbf{x}}$ \\
\hline $0-38$ & immature stage & & & \\
$39-40$ & pre-oviposition & & & \\
41 & 0.38 & 31.84 & 12.10 & 496.10 \\
42 & 0.36 & 27.61 & 9.94 & 417.48 \\
43 & 0.33 & 25.53 & 8.42 & 362.06 \\
44 & 0.28 & 22.75 & 6.37 & 280.28 \\
45 & 0.26 & 21.05 & 5.47 & 246.15 \\
46 & 0.22 & 18.17 & 4.00 & 184.00 \\
47 & 0.19 & 15.8 & 3.00 & 141.00 \\
48 & 0.15 & 14.11 & 2.12 & 101.76 \\
49 & 0.13 & 9.33 & 1.21 & 59.29 \\
50 & 0.1 & 6.73 & 0.67 & 33.50 \\
51 & 0.09 & 4.36 & 0.39 & 19.89 \\
52 & 0.07 & 3.11 & 0.22 & 11.44 \\
53 & 0.06 & 2.21 & 0.13 & 6.89 \\
54 & 0.03 & 1.77 & 0.05 & 2.70 \\
55 & 0.02 & 0.62 & 0.01 & 0.55 \\
56 & 0.02 & 0.3 & 0.01 & 0.56 \\
57 & 0.01 & 0 & 0.00 & 0.00 \\
\hline Total & & 205.29 & 54.12 & 2363.65 \\
\hline
\end{tabular}

The present study evident that host plant species extremely affected by the biological attributes instance as development, fecundity, and life table parameters of the vine mealybug, $P$. ficus (Signoret). Innate capacity for increase $(r)$ and finite rate of increase $(\lambda)$ of the vine mealybugs reared on three ornamental plants were significantly different.

Table (7) describes the population and reproductive parameter of $P$. ficus. The Innate capacity for increase $(r)$ was the highest in populations reared on $H$. helix (0.17). Identically, the highest net reproductive rate (Ro) was observed on H. helix (105.08). Results in Table (7) also showed that the doubling time $\left(\mathrm{D}_{\mathrm{T}}\right)$ was recorded (4.08, 6.93 and 7.70) on H. helix L., P. tobira (Thunb.) and $N$. oleander L. respectively, which clarified the effect of food and determined that the vine mealybug preference the leaves of $H$. helix compared with the leaves of $P$. tobira and $N$. oleander. Mean generation time $(\mathrm{T})$ displayed a clear difference in mealybugs reared on the various host. The longest mean generation time was instituted on mealybugs breed on $N$. oleander and $P$. tobira, but the shortest mean generation time was observed in mealybugs breeding on $H$. helix. As for the fertility of females, it has reached the highest total of age-specific fertility $\left(\Sigma \mathrm{m}_{\mathrm{x}}\right)$ around 270.85 on $H$. helix leaves. The intrinsic rate of natural increase was first utilized by Birch (1948) as a measurement of animal population increase average and since then, used on numerous insects Lee et al. (2002). 
Table 7. Population and reproductive parameters of vine mealybug, P,ficus on three omamental plants under laboratory conditions

\begin{tabular}{lccc}
\hline Parameters & $\begin{array}{c}\text { Headra } \\
\text { helix }\end{array}$ & $\begin{array}{c}\text { Pottosporum } \\
\text { tobira }\end{array}$ & $\begin{array}{c}\text { Nerium } \\
\text { Oleander }\end{array}$ \\
\hline $\mathrm{R}_{0}$ & 105.08 & 58.90 & 54.11 \\
$\mathrm{~T}$ & 27.42 & 40.33 & 43.68 \\
$\mathrm{r}$ & 0.17 & 0.10 & 0.09 \\
$\lambda$ & 1.85 & 1.11 & 1.09 \\
$\mathrm{D}_{\mathrm{T}}$ & 4.08 & 6.93 & 7.70 \\
$\sum \mathrm{M}_{\mathrm{x}}$ & 270.85 & 207.02 & 205.29 \\
\hline
\end{tabular}

In this study, the evolution and life table parameters of $P$. ficus were studies on the three various ornamental plants. $P$. ficus accomplished its development and reproduce on all the examined plants. Knowing the life table parameters of P. ficus on different host plants will assistance in the protection and forecast of its population development, which will lead to the enforcement of programs to decrease economic losses. Subsequently, the perception the life cycle of the mealybug on diverse host plants is fateful for the evolution of the program of pest control. Based on the results obtained, the vine mealybug $P$. ficus can be considered a menace to the husbandry of decorative plants in great capitals, orchard and famous squares. If the environmental conditions are appropriate, the mealybug population will augmentation fastly in a stumpy period and cause important spoilage to ornamental plants. In addition, the vine mealybug $P$. ficus has a wide host range encompass of fruits, vegetables, field crops as well as ornamental plants and weeds, consequently P. ficus considered as an important pest in any agricultural system.

\section{REFERENCES}

Ahmed, N. H. and Abd-Rabou, S. M. (2010): Host plants, geographical distribution, natural enemies and biological studies of the citrus mealybug, Planococcus citri (Risso) (Hemiptera: Pseudococcidae). Egypt. Acad. J. biolog. Sci., 3 (1): 39- 47.

Arif, M. J.; Rafiq, S. M.; Dildar, G.M.; Arshad, M. and Aslam, K. M. (2013): Studies on biological parameters of an invasive mealybug, Phenacoccus solenopsis Tinsely (Pseudococcidae: Hemiptera) on different host plants under laboratory conditions. Acad. J. Entomol., 6(2): 55-60.

Ataş, M. and Kaydan, M.B. (2014): Investigations on biological characteristics of Pseudococcus comstocki (Kuwana) (Hemiptera: Pseudococcidae) on different two mulberry species and different temperatures. Türk. Entomol. Derg., (38):71-81.

Bernays, E.A. and Chapman, R.F. (1994): Host-plant selection by phytophagous insects. Chapman and Hall, New York, 312 pp.

Birch, L. C. (1948): The intrinsic rate of natural increase of an insect population. J. Anim. Ecol., 17(1): 15-26.

Cabaleiro, C. and Segura, A. (1997): Field transmission of grapevine leafroll associated virus 3 (GLRaV3 ) by the mealybug, Planococcus citri. Plant Dis. 81:283-288.
Carey, J.R. (1993): Applied demography for biologists with special emphasis on insects. Oxford University Press, New York, USA, 206 pp.

Chi, H.and Su, H.Y. (2006): Age-stage, two-sex life tables of Aphidius gifuensis (Ashmead) (Hymenoptera: Braconidae) and its host Myzus persicae (Sulzer) (Homoptera: Aphididae) with mathematical proof of the relationship between female fecundity and the net reproductive rate. Environ. Entomol., 35 (1): 10-21.

Daane, K.M.; Almeida, R.P.P.; Bell, V.A.; Walker, J.T.S.; Botton, M.; Fallahzadeh, M.; Mani, M.; Miano, J.L.; Sforza, R.; Walton, V.M. and Zaviezo, T. ( 2012): Biology and management of mealybugs in vineyards. In: Bostanian, N.J., Charles, V., Isaacs, R. (Eds.), Arthropod Management in Vineyards: Pests, Approaches, and Future Directions. Springer, New York, pp. 271-307.

Daane, K.M.; Bentley,W.J.; Walton, V.M.; MalakarKuenen, R.; Millar, J.G; Ingels, C.A.; Weber, E.A. and Gispert, C. (2006): New controls investigated for vine mealybug. Calif. Agr., 60:31-38.

Filiz, A. C.; Bora, M. K.; Murat, M. and Rifat, M. U. (2016): Demographic parameters and biological features of Phenacoccus solenopsis Tinsley (Hemiptera: Pseudococcidae) on four ornamental plants, Phytoparasitica, (44):75-82.

Hogendorp, B.K.; Cloyd, R.A. and Swiader, J.M. (2006): Effect of nitrogen fertility on reproduction and development of citrus mealybug, Planococcus citri Risso (Homoptera: Pseudococcidae), feeding on two colors of coleus, Solenostemon scutellarioides L. Codd. Environ. Entomol., (35): 201-211.

Holat, D.; Kaydan, M.B. and Muştu, M. (2014): Investigations on some biological characters of Pseudococcus cryptus (Hempel) (Hemiptera: Pseudococcidae) on four citrus species. Acta. Zoolog. Bulg., (6):35-40.

Kosztarab, M. and Kozar F. (1988): Scale insects of central Europe. Series Entomologica Vol.( 41): Akademiai Kiado. Budapest, 456 pp.

Kumar, S.; Kular, J. S.; Mahal, M. S. and Dhawan, A. K. (2013): Life table of Phenacoccus solenopsis Tinsley (Pseudococcidae: Hemiptera) on various phonological stages of cotton. Afr. J. Agr. Res., 8 (17): 1669-1676.

Lee, J. H.; Lee, K. S. and Lee, H. P. (2002): Life table descriptions of Tetrastichus sp. (Hymenoptera: Eulophidae) on Hyphatria cunea Drury. Kor. J. Biol. Sci., 6(1): 19-22.

Mastoi, M. I.; Azura, A. N.; Muhamad, R.; Idris, A. B. and Ibrahim, Y. (2011): First report of papaya mealybug, Paracoccus marginatus (Hemiptera: Pseudococcidae) from Malaysia. Aust. J.of Bas. and Appl. Sci., 5 (7): 1247-1250. 
Mastoi, M. I.; Nur Azura, A.; Muhamad, R.; Idris, A. B. ; Arfan, A. G. and Ibrahim, Y. (2014): Life table and demographis parameters of Papaya mealybug, Paracoccus marginatus (Hemiptera: pseudococcidae) on Hibiscus rosa-chinensis. Sci. Int. - (Lahore), 26 (5): 2323-2329.

Patil, S.V.; Chandrashekhar, D.P.; Rahul, B.S.; Vijay, L.M. and Bipinchandra, K.S. (2011): Studies on life cycle of mealybug, Maconellicoccus hirsutus (Green) (Hemiptera: Pseudococcidae), on different hosts at different constant temperatures. J.of Crop. Protect., (30):1553-1556.

Pearl, R. (1928): The Rate of Living. Knopf, New York, NY,443 pp.

Polat, F.; Ülgenturk, S. and Kaydan, M.B. (2008): Developmental biology of citrus mealybug, Planoccoccus citri (Risso), (Hemiptera: Pseudococcidae), on ornamental plants. In: Proceedings of the XI international symposium on scale insect studies, Lisbon, 177-184.

Price, P.W.; Bouton, C.E.; Gross, P.; McPheron, B.A.; Thompson, J.N. and Weis, A.E. (1980): Interactions among three trophic levels: influence of plant interactions between insect herbivores and natural enemies. Annu. Rev. Ecol. Systemat., 11:41-65.

Rashid, M.M; Khattak, M.K. and Abdullah, K. (2012): Phenalogical Response of Cotton Mealybug, Phenacoccus solenopsis $\mathrm{T}$ to three prominent host Plants. Pakistan. J. Zool., 22(2):341-346.

Schowalter, T. D. (2011): Insect Ecology: An Ecosystem Approach (Third ed.): Elsevier. pp. 650.

Sforza, R.; Kirk, A. and Jones, W.A. (2005): Results of foreign exploration for natural enemies of Planococcus ficus (Hom.:Pseudococcidae), a new invasive mealybug in California vineyards. AFFP - 7EME Conference International Sur Les Ravageurs en Agriculture, 1-8.
Siswanto, M. R.; Omar, D. and Karmawati, E. (2008): Life table and population parameters of Helopeltis antonii (Hemiptera: miridae) reared on cashew (Anacardium occidentalel). J. Biosci., 19(1): 91-101.

Southwood, T. R. E. (1978): Ecological methods with particular reference to the study of insect populations. 2nd Edition. Chapman and Hall. pp. 524.

Sule, H.; Muhamad, R.; Omar, D. and Hee, A. (2012): Life table and demographic parameters of Asian citrus psyllid Diaphorina citri on limau madu Citrus suhuiensis. J. Entomol., 9(3): 146-154.

Tobih, F.O.; Omoloye, A.A.; Ivbijaro, M.F. and Enobakhare, D.A. (2002): Effects of field infestation by Rastrococcus invadens Williams (Hemiptera: Pseudococcidae) on the morphology and nutritional status of mango fruits, Mangifera indica L. Crop Protect., (21):757-761.

Tok, B.; Kaydan, M.B.; Mustu,M. and Ulusoy,M.R. (2016): Development and life table parameters of Phenacoccus madeirensis Green (Hemiptera: Pseudococcidae) on four ornamental plants. Neotropical Entomol., (45):389-396.

Win S. S.; Ahmad, Z. A. M. and Adam, N. A. (2011): Life table and population parameters of Nilaparvata lugens Stal. (Homoptera: Delphacidae) on rice. Trop. Life. Sci. Res., 22(1): 27-39.

Yang, J. and Sadof, C.S. (1995): Variegation in Coleus blumei and the life history of citrus mealybug (Homoptera: Pseudococcidae). Environ. Entomol., (24):1650-1655.

Yang, X.B.; Zhang, Y.M.; Henne, D.C.and Liu, T.X. (2013): Life tables of Bactericera cockerelli (Hemiptera: Triozidae) on tomato under laboratory and field conditions in Southern Texas. Florida Entomol., 96 (3): 904-913.

\section{مقارنة جداول الحياة لبق العب الدقيقى (Planococcus ficus (Signoret)، على بعض أنواع نباتات الزينة غادة صلاح محمد قسم وقاية النباتات ـ كلية الز ارعة ارعة - جامعة جنوب الوادى ـ قنا}

\footnotetext{
استهدف البحث در اسـة لكافـة المقاييس الحياتيـة ومقاييس الخصوبة والقابلية على التكاثر و الإنتاجية لحشرة بـق العنب الدقيقى Planococcus ficus (Signoret) (Hemiptera: Pseudococcidae)

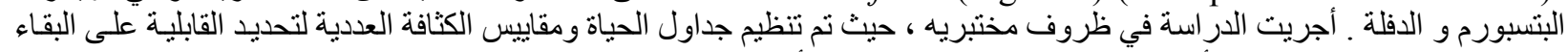

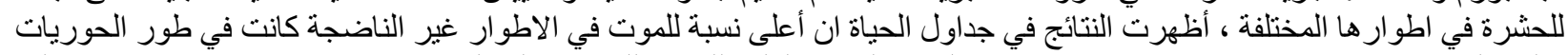

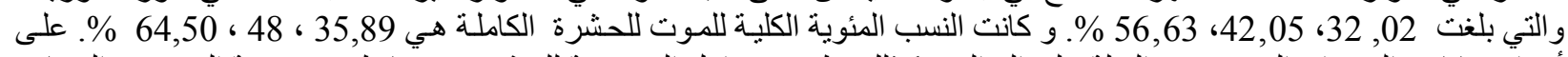

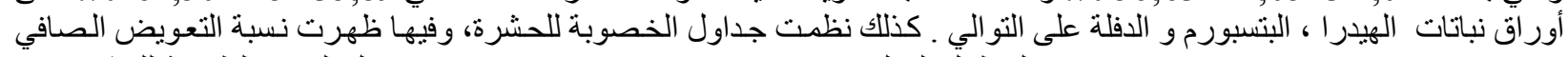

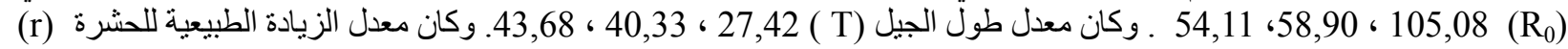

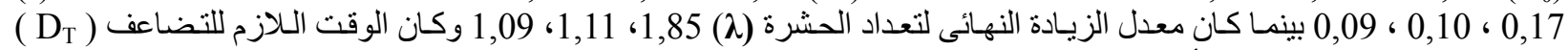

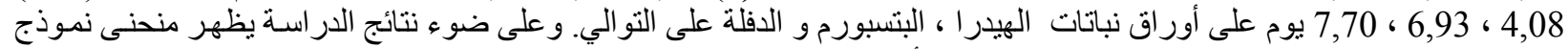

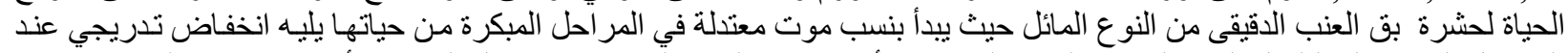

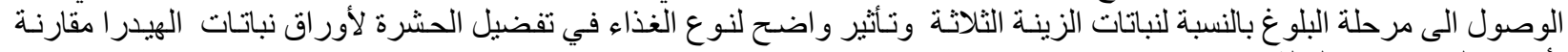
بأوراق البتسبورم و الدفلة.
} 